\title{
ECOLOGICAL ASPECTS OF PHENOL DECOMPOSITION IN THE BASIS OF PHOTOLYSIS REACTIONS
}

\author{
E.M.Gadirova \\ Baku State University \\ Received 26.01.2019 \\ Accepted 21.10.2019
}

\begin{abstract}
For the first time, there was carried out photochemical dissociation of phenol in the presence of $\mathrm{TiO}_{2}$ nanoparticles and methyl-3-aminocrotonate. It is established that $80 \%$ of phenol was decomposed. The process lasted for two hours. Results are confirmed by the mass-chromatography. The nanocrystalline $\mathrm{TiO}_{2}$ powders were composed of rutile form $\mathrm{TiO}_{2}$ obtained by XRD. The size of nanoparticles was examined by transmission electron microscopy analysis and is about 10-20 nm, general surface area of nanoparticles made up $159.6 \mathrm{~m}^{2} / \mathrm{g}$. The photolysis process was carried out at UV radiation and the coefficient dependence on the wavelength was determined by the "Varian" device.
\end{abstract}

Keywords: UV radiation, methyl-3-aminocrotonate, phenol, degradation, $\mathrm{TiO}_{2}$ nano-particles and etc. doi

\section{Introduction}

In modern era heterogenic photocatalysis is considered one of the most effective processes in the environmental protection and treatment of waste waters from phenol-type combinations. Water pollution has become a major problem in recent years. The biological, chemical, and physico-chemical water treatment methods are often ineffectively or environmentally incompatible. Reduction in the fresh water reserve, growth in the amount of waste water is increases the demand to the clean water or purified water. In this regard, different cleaning methods are proposed for dissociation of organic toxic substances from the waste water. As it is impossible to carry out complete treatment with the classic chemical, physical and biological methods in this case, recently the process of working out new methods is going on $[1,2]$. In this direction the treatment of waste water was achieved by using nanoparticles. In this regard, recently effective treatment methods by using nanoparticles have got a wide scope [3]. Phenol is always encountered in waste water as it is obtained from petroleum chemistry, medicine, plastics, coal production, and color and paper production. Generally, phenol is one of the most important contaminators because of high toxicity in the regard of its weak biological dissociation, being in high concentration and harmful influence to environment for a long time [4]. As it is noted, gradual reduction of clean water and in- crease of contamination are already among the significant ecological issues in the world. Currently, millions of people are suffering from the shortage of fresh water in the world. Totally, phenol, the most important of water contaminators leads to significant ecological problems. So far many methods have been used for removal of the phenol from waste water. Usage of physical, chemical and biological methods is less trendy today $[5,6]$. During the chemical processing intervening products are obtained so that they are also harmful for environment. Biological processing methods are less influencing the acceleration of biological reactions, and in physical treatment absorption and membrane filtration methods are mainly used [7]. Membrane filtration is a unique method for treatment of water from contaminating substances, i.e.; currently, the method of membrane filtration is paid much attention as an effective process in the regard of ecology and energy effectiveness for the water treatment. However at this time dissociation of toxic substances in the composition of water requires other methods. Therefore, the subject of working out the new methods does not lose its actuality. Besides, there are other scientific themes in this direction.

It is known from the literature that, doping $\mathrm{TiO}_{2}$ with various elements is the most effective way to narrow its band gap. Among these dopants, nitrogen has attracted much attention in recent years due to its small ionization energy, comparable atomic size with oxygen, meta- 
stable center formation, and enhanced UV- Vis photocatalytic performance. Many works on the preparation of $\mathrm{N}-\mathrm{TiO}_{2}$ by physical or chemical methods have been published. Among these methods, $\mathrm{N}-\mathrm{TiO}_{2}$ powders were mainly prepared either by calcination of $\mathrm{TiO}_{2}$ powders under nitrogen containing atmosphere or by postheat treatment of the Sol-Gel/hydrothermally prepared amorphous $\mathrm{TiO}_{2}$ with nitrogen agents at high temperature for both doping nitrogen atoms into the $\mathrm{TiO}_{2}$ lattice and crystallization. However, calcination under high temperature may cause agglomeration and abnormal growth of crystals which results in small surface area and decreases the number of photoactive sites. So, it is necessary to seek an appropriate route to synthesize $\mathrm{N}-\mathrm{TiO}_{2}$ effectively under mild conditions. However, it is not so easy to dope nitrogen into $\mathrm{TiO}_{2}$ under mild hydrothermal conditions because the bond energy between Ti-O is greater than that of Ti-N bond. Some researchers have tried to synthesize N$\mathrm{TiO}_{2}$ powders by one- step hydrothermal method without postheat treatment in a relatively lower temperature. It was found that $\mathrm{N}-\mathrm{TiO}_{2}$ could be synthesized through one-step hydrothermal method at $150^{\circ} \mathrm{C}$ for $8 \mathrm{~h}$. $\mathrm{N}-\mathrm{TiO}_{2}$ nanoparticles were prepared [8]. From this point of view, we used nitrogen compounds together with $\mathrm{TiO}_{2}$ nanoparticles.

\section{Experimental part}

The reaction of phenol dissociation through photochemical reactions by using $\mathrm{TiO}_{2}$ nanoparticles and methyl-3-aminocrotonate for the treatment of phenol from waste water has been carried out for the first time by us. For this purpose, there was prepared the solution $0.05 \mathrm{~g}$ $\mathrm{TiO}_{2}$ and methyl-3-aminocrotonate being in of $0.05 \mathrm{~g}$ weight equally distributed in the distillation water of $10 \mathrm{ml}$. As it is mentioned above, $\mathrm{TiO}_{2}$ nanoparticles are not dangerous for environment, are considered ecologically clean in the regard of toxic and gets excited by UV radiation and serves to the processing of the reaction. Complete mixing of $\mathrm{TiO}_{2}$ nanoparticles in the participation of UV radiation has been carried out in advance for their equal distribution in the distillation water. $5 \mathrm{ml}$ has been added to $20 \mathrm{ml} 1 \mathrm{mg} / \mathrm{l}$ phenol solution (totally $25 \mathrm{ml}$ ) by being taken from the obtained solution and then $0.05 \mathrm{~g}$ methyl-3-aminocrotonate has been added. The viewed mixture has been subject to photochemical dissociation for 60 minutes. After photolysis process the dependence of the absorption coefficient of reaction solution on the wavelength has been drawn on UV radiation device. On the basis of the obtained curves the photolytic dissociation has been proved. The photolysis process has been carried out in UV radiation device; the dependence of absorption coefficient on the wavelength has been determined by "Varian" device, the concentration of phenol remained in the solution after photochemical reaction has been determined upon the degreed graphics. Photolytic dissociation has been $80 \%$. The phenol degradation was calculated using quantitative analysis, carried out on a $6890 \mathrm{~N}$ GC-MSD gas chromatograph with an Agilent 5975 high-performance massselective detector.

$20 \mathrm{ml}$ from $1 \mathrm{mg} / \mathrm{l}$ phenol solution, $5 \mathrm{ml}$ from the solution full equal disturbing $0.05 \mathrm{~g}$ $\mathrm{TiO}_{2}$ nanoparticles in it and $0.05 \mathrm{~g}$ methyl-3aminocrotonate have been taken for using in the process. Crotonats are usually used as fungicides. They are not dangerous for the environment.

\section{Analysis of the results and discussion}

The purity and crystalline properties of the $\mathrm{TiO}_{2}$ nanoparticles were investigated by powder X-ray diffraction (XRD) method. Figure 1 shows the XRD patterns of the synthesized $\mathrm{TiO}_{2}$ nanopowders. All the XRD peaks were well defined and corresponded to $\mathrm{TiO}_{2}$ at rutile phase. From the line broadening of the (101) diffraction peak by Scherrer's method, the average crystal size of $\mathrm{TiO}_{2}$ is about 10.3. The specific surface areas for $\mathrm{TiO}_{2}$ is $159.6 \mathrm{~m}^{2} / \mathrm{g}$. In the pattern all lines can be indexed, using the ICDD (PDF-2/ Release 2011 RDB) DB card number 00-001-1292. The pattern of $\mathrm{TiO}_{2}$ nanopowder has characteristic peaks at $27.90^{\circ}$ (110), 36.01 ${ }^{0}(101), 41.58^{0}(111), 54.71^{0}(211)$. 


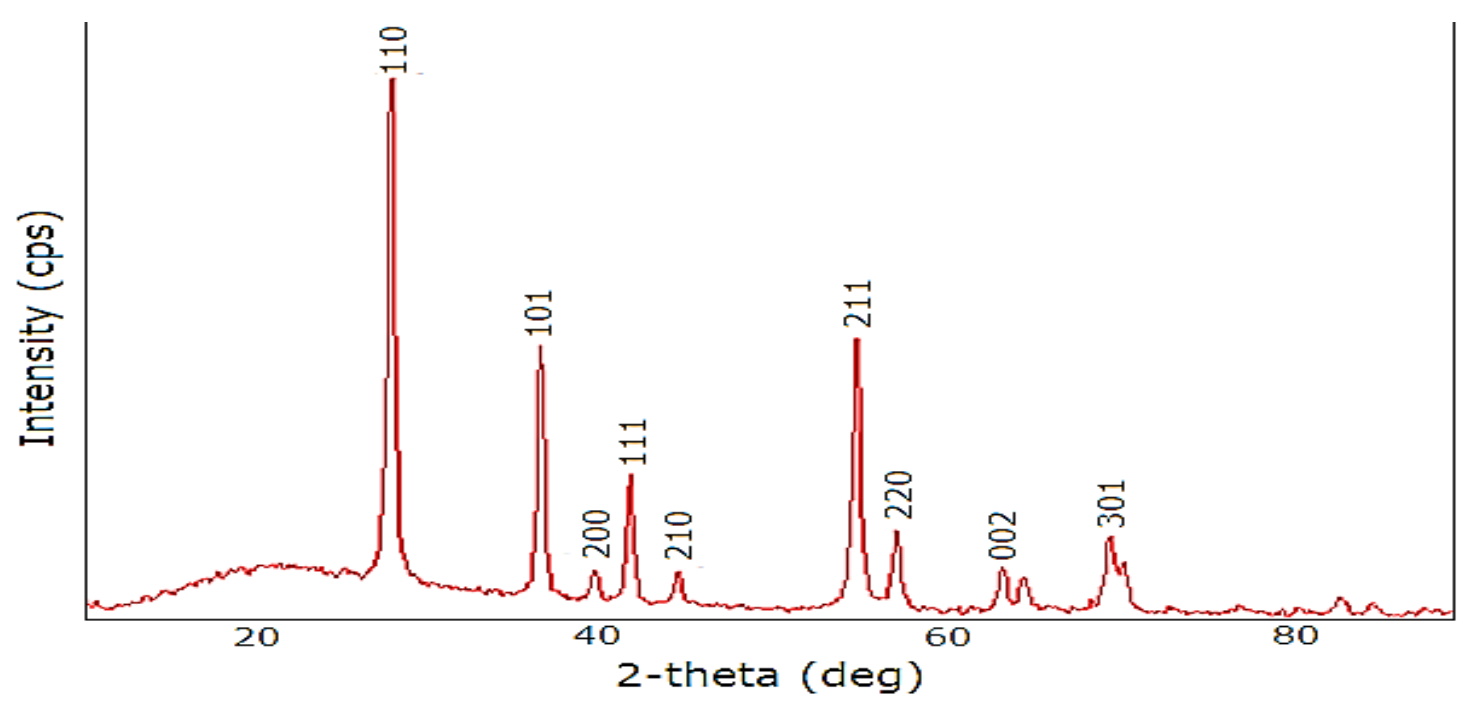

Fig. 1. XRD patterns of the $\mathrm{TiO}_{2}$ nanopowders

The prepared $\mathrm{TiO}_{2}$ nanopowders were analysed by transmission electron microscopy (TEM) method, and the results are presented in Figure 2. As it seen from Figure 2, the obtained nanoowder grain sizes are homogenous and vary in the range from 10 to $15 \mathrm{~nm}$. The data of TEM analysis very well correlate with the results, obtained from XRD analysis.

Figure 2 shows the TEM micrograph $\mathrm{TiO}_{2}$ nanopowders. The particles are spherical in shape and $10 \mathrm{~nm}$ in size, which is consistent with the results calculated by Scherrer's method.

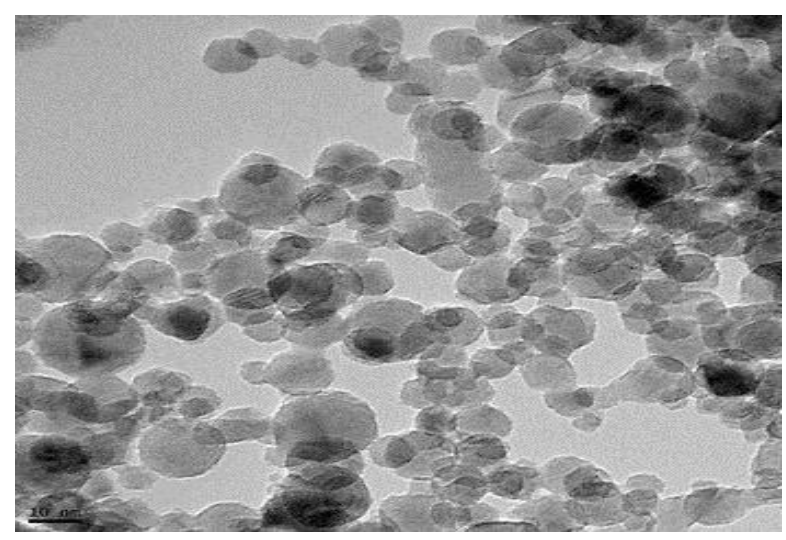

Fig. 2. TEM micrograph of synthesized $\mathrm{TiO}_{2}$ powders.

The works on the treatment of phenol from waste water in the participation of other composites with nanoparticles are encountered in the world literature. It may be noted by refer- ring to the information that $\mathrm{TiO}_{2}$ nanoparticles has very good photo-dissociation together with combinations with $\mathrm{N}$ atom [9-12]. And why has namely the usage of $\mathrm{TiO}_{2}$ been paid less? The matter is that we have considered more appropriate $\mathrm{TiO}_{2}$ nanoparticles because the works to be done by us have been carried out in the participation of UV radiation, since $\mathrm{TiO}_{2}$ nanoparticles gets excited only during UV radiation (A<387 mm), only 5\% of excitement in the visible region [13-17]. Furthermore, $\mathrm{TiO}_{2}$ is chemically sustainable, it is obtained in soft condition, that's easily in the viewed case, and the most important is that it is considered ecologically clean [18-20].

Graphic 1 presents the dependence of absorption coefficient of the $5 \mathrm{ml}$ solution with $\mathrm{TiO}_{2}, 20 \mathrm{ml}$ from $1 \mathrm{mg} / \mathrm{l}$ phenol solution, methyl 3-aminocrotonate before the radiation on the wave length. It is clear from the graphic curve that the existence of curve in the $270 \mathrm{~nm}$ part which is characteristic for phenol in the solution is the evidence of the presence of the same substance.

In Graphic 2 the comparison of the curves obtained after photolysis process is given. It is seen from the graphic that the curves which are characteristic for phenol $(270 \mathrm{~nm})$ reduced gradually so that there occurs the dissociation of the keratin part of phenol in the process. 


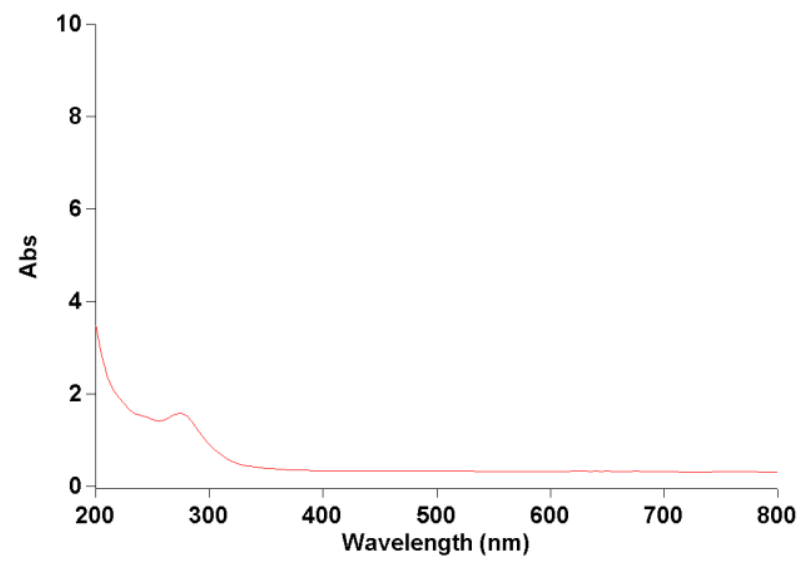

Graphic 1. UV-radiation curve of phenol+methyl-3-amincrotonate $+\mathrm{TiO}_{2}$ solution before the radiation

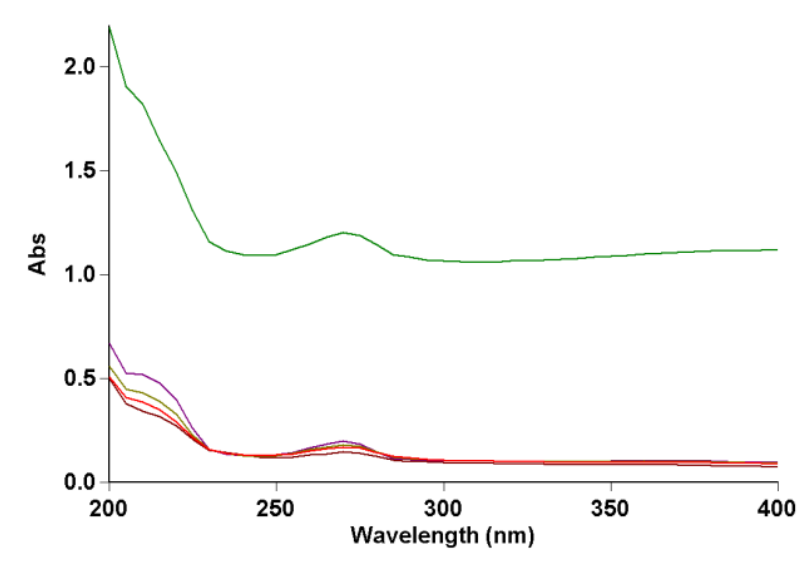

Garphic 2. Diagram of reduction of phenol the concentration in the solution of UV radiation in the system of $\mathrm{TiO}_{2}+$ methyl3aminocrotonate+phenol.

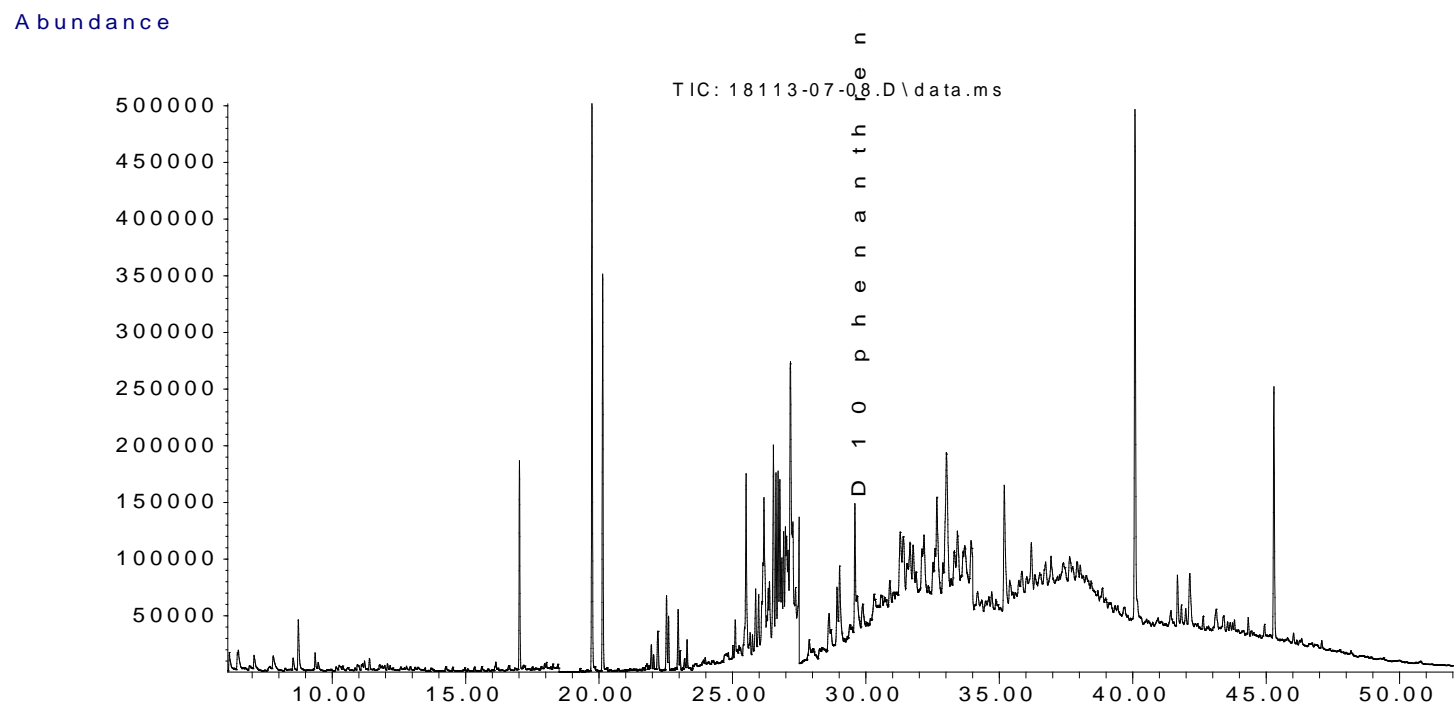

Tim e-->

Fig. 3. The general view of the chromatographic curves of the $\mathrm{TiO}_{2}+$ methyl 3-aminocrotonate+phenol

The sample was then analyzed in a gas chromatographic mass detector for more sensitive and accurate analysis and the results of the composition and quantitative analysis of the solution are shown in Table.

As can be seen from the table, the amount of phenol has dropped from $1 \mathrm{mg}$ (1000 $\mathrm{mcg}$ ) to $200 \mathrm{mcg}$. This means that, $80 \%$ of phenol has degraded.Belay cited the chromatographic curves of the sample after the photolysis process (Figure 3 ).

This article is aimed at the solution of ecological problems for the environmental protection.
Analysis of $1 \mathrm{mg} / \mathrm{l}$ phenol+ $\mathrm{TiO}_{2}+$ methyl 3-aminocrotonate solution by mass spectroscopy after photolysis

\begin{tabular}{|l|c|}
\hline \multicolumn{1}{|c|}{ Substances } & Sample \\
\cline { 2 - 2 } & concentration, mcg/l \\
\hline phenol & 200 \\
\hline o-cresol & 96 \\
\hline m+p-methylphenol & 98 \\
\hline 2-nitrophenol & 5 \\
\hline 2,4-dimethylphenol & 24 \\
\hline 2,6-dichlorphenol & 18 \\
\hline 4-chloro-3-methylphenol & 24 \\
\hline 2,4,5-TCP & 34 \\
\hline 2,4,6-TCP & 2.1 \\
\hline 2,3,4,6-tetrachlorophenol & 0.3 \\
\hline pentachlorphenol & 0.2 \\
\hline
\end{tabular}


So, the dissociation of toxic substances from contaminated water through nano-particles is considered one of the most important and topical issues. In the modern area the contamination of water basin is the most vital of the global ecological problems. As the fresh water reserve is getting reduced, maximum working out the treatment methods of waste water and reducing the toxic substances to minimum are the significant most topical issues.

\section{Conclusion}

1. The sizes of $\mathrm{TiO}_{2}$ nanoparticles are homogeneous and vary between $10-20 \mathrm{~nm}$, the results are according to the calculations with Scherer method. General surface area of nanoparticles has consisted of 159.6 $\mathrm{m}^{2} / \mathrm{g}$. TEM results coincide with the results obtained from the analysis of XRD.

2. Dissociation of phenol from phenol solution in the participation of methyl 3-aminocrotonate and upon the photo-analytic characteristics of synthesized $\mathrm{TiO}_{2}$ nanoparticles has been carried out with UV radiation.

3. Dissociation of phenol in the participation of $\mathrm{TiO}_{2}$ nanoparticles and methyl 3-aminocrotonate made up $80 \%$.

4. The present article has described an investigation of $\mathrm{TiO}_{2}$ nanoparticles for the treatment of toxic substances in water basins as a means of protecting the environment.

\section{References}

1. De Luis M., Lombrana J.I., Menendez A., Sanz J. Analysis of the toxicity of phenol solutions treated with $\mathrm{H}_{2} \mathrm{O}_{2} / \mathrm{UV}$ and $\mathrm{H}_{2} \mathrm{O}_{2} / \mathrm{Fe}$ oxidative systems. Ind. Eng. Chem. Res. 2011. V. 50. No 4. P. 19281937.

2. Gumush D., Akbal F. Photocatalytic degradation of textile dye and wastewater. Water, Air, and Soil Pollution. 2011. V. 216. No 1-4. P. 117-124.

3. Hu Xuebing, Yu Yun, Ren Shuang, Lin Na, Wang Yongqing, Zhou Jianer. Highly efficient removal of phenol from aqueous solutions using graphene oxide $/ \mathrm{Al}_{2} \mathrm{O}_{3}$ composite membrane. J. Porous Materials. 2018. V. 25. No 3. P. 719-726.

4. Santhosh C., Velmurugan V., Jacob G., Jeong S.K., Grace A.N., Bhatnagar A., Role of nanomaterials in water treatment applications: a review. Chem. Eng. J. 306. 2016. P. 1116-1137.
5. Wang F., Novel high performance magnetic activated carbon for phenol removal: equilibrium, kinetics and thermodynamics. J. Porous Mater. 2017. V. 24. P. 1-9.

6. Mohammadi S., Kargari A., Sanaeepur H., Abbassian K., Najafi A., Mofarrah E. Phenol removal from industrial wastewaters: a short review. Desalin. Water Treat. 2015. V. 53. P. 2215-2234.

7. Gosling S.N., Arnell N.W. A global assessment of the impact of climate change on water scarcity. Clim. Change 134. 2016. P. 371-385.

8. Junna Xu, Feng Wang, Wenxiu Liu, Wenbin Cao. Nanocrystalline N-Doped $\mathrm{TiO}_{2}$ Powders: Mild Hydrothermal Synthesis and Photocatalytic Degradation of Phenol under Visible Light Irradiation. Hindawi Publishing Corporation. China. 2013. P. 1-7.

9. Yue D., Qian X., Zhao Y. Photocatalytic remediation of ionic pollutant. Science Bulletin. 2015. V. 60. No 21. P. 1791-1806.

10. Qiu X., Burda C. Chemically synthesized nitrogen-doped metal oxide nanoparticles. Chem. Physics. 2007. V. 339. No 1-3. P. 1-10.

11. Li Y., Cao W., Ran F., Zhang X. Photocatalytic degradation of methylene blue aqueous solution under visible light irradiation by using N-doped titanium dioxide. Key Engineering Materials. V. 336-338. P. 1972-1975.

12. Fujishima A., Rao T.N., Tryk D.A. Titanium dioxide photocatalysis. J. Photochem. Photobiology. C. 2000. V. 1. No 1. P. 1-21.

13. Kim Y., Yang S., Jeon E.H., Baik J., Kim N., Kim H.S., Lee H. Enhancement of photo-oxidation activities depending on structural distortion of Fedoped $\mathrm{TiO}_{2}$ nanoparticles. Nanoscale Res. Lett. 2016. P. 11-41.

14. Chen X.B., Mao S.S. Titanium dioxide nanomaterials: synthesis, properties, modifications, and applications. Chem Rev. 2007. V. 107. No 7. P. 2891-2959.

15. Ioannou L.A., Puma G.L., Fatta-Kassinos D. Treatment of winery wastewater by physicochemical, biological and advanced processes: a review. J. Hazard. Mater. 2015. V. 286. P. 343-368.

16. Liu R.L., Ye H.Y., Xiong X.P., Liu H.Q. Fabrication of $\mathrm{TiO}_{2} / \mathrm{ZnO}$ composite nanofibers by electrospinning and their photocatalytic property. Mater Chem Phys. 2010. V. 121. No 3. P. 432-439.

17. Kosowska S., Mozia A., Morawski W., Grzmil B., Janus M., Kalucki K. The preparation of $\mathrm{TiO}_{2}$ nitrogen doped by calcination of $\mathrm{TiO}_{2}-\mathrm{xH}_{2} \mathrm{O}$ under ammonia atmosphere for visible light photocatalysis. Solar Energy Materials and Solar Cells. 2005. V. 88. No 3. P. 269-280.

18. Baruwati, Varma R.S. Synthesis of N-doped nano $\mathrm{TiO}_{2}$ using guanidine nitrate: an excellent visible light photocatalyst. J. Nanoscience and Nanotechnology. 2011. V. 11. No 3. P. 2036-2041. 
19. Livraghi S., Czoska A.M., Paganini M.C., Giamello E. Preparation and spectroscopic characterization of visible light sensitized $\mathrm{N}$ doped $\mathrm{TiO}_{2}$ (rutile). J. Solid State Chem. 2009. V. 182. No 1. P. 160-164.
20. Darienzo M., Scotti R., Wahba L. Hydrothermal $\mathrm{N}$-doped $\mathrm{TiO}_{2}$ : explaining photocatalytic properties by electronic and magnetic identification of N active sites. Applied Catalysis. B. 2009. V. 93. No 1-2. P. 149-155.

\section{FOTOLIZ REAKSIYALARINA OSASЭN FENOLUN PARÇALANMASININ ECOLOJİ ASPEKTLӘRI \\ E.M.Qədirova}

İlk dəfə olaraq $\mathrm{TiO}_{2}$ nano hissəcikləri və metil3-aminokrotonat iştirakında fenolun fotokimyəvi kimyəvi parçalanması aparılmış və fenolun $80 \%$ parçalanması müəyyən edilmişdir. Proses iki saat davam etmişdir. Nəticələr kütlə xromatoqrafiyası ilə təsdiq edilmişdir. $\mathrm{TiO}_{2}$ nano hissəciklərinin $\mathrm{TiO}_{2}$-nin rutil formasından ibarətdir və XRD metodu ilə təyin edilmişdir. Nano hissəciklərin ölçüsü transmissiya elektron mikroskopu ilə tədqiq edilmiş və təxminən 10-20 $\mathrm{nm}$ arasında olmuş, onların ümumi sahəsi isə $159.6 \mathrm{~m}^{2} / \mathrm{q}$ təşkil etmişdir. Fotoliz prosesi UB şüalandırıcı cihazda aparılmış və udma əmsalının dalğa uzunluğundan asılılı̆̆ "Varian" cihazı ilə müəyyən edilmişdir.

Açar sözlar: UV radiasiya,metil3-aminokrotonat, fenol, parçalanma, $\mathrm{TiO}_{2}$ nanohissacikar vas.

\section{ЭКОЛОГИЧЕСКИЕ АСПЕКТЫ РАЗЛОЖЕНИЯ ФЕНОЛА НА ОСНОВЕ РЕАКЦИЙ ФОТОЛИЗА}

\section{Е.М.Кадырова}

Впервые была проведена фотохимическая диссоциация фенола в присутствии наночастиц ТіО 2 и метил3аминокротоната. Было выявлено, что $80 \%$ фенола разлагался. Процесс длился два часа. Результаты подтверждены методом масс-хроматографии. Нанокристаллические порошки $\mathrm{TiO}_{2}$ были составлены из рутиловой формы $\mathrm{TiO}_{2}$, определенной методом РСА. Размер наночастиц исследован с помощью просвечивающей электронной микроскопии и составлял около 10-20 нм, общая площадь поверхности наночастиц составляла 159.6 м²/ г. Процесс фотолиза проводился при УФ излучении, и зависимость коэффициента от длины волны определялась прибором "Varian".

Ключевые слова: УФ-излучение, метил 3-аминокротонат, фенол, разложение, $\mathrm{TiO}_{2}$ нано частицы и др. 